\title{
Equal Employment Rights of the Roman Army Administration: An Archetype of Modern Day Human Resource Management
}

\author{
Thaweesakdhi Suvagondha \\ Professor of Business Administration, Thammasat Business School, \\ Thammasat University, Thailand
}

Doi: 10.19044/esj.2018.v14n13p256 URL:http://dx.doi.org/10.19044/esj.2018.v14n13p256

\begin{abstract}
Gaius Marius introduced a new act during his first consulship of the Roman Republic in 107 B.C. with the approval of the Senate. This act allowed him to alter the strategy for managing the Roman army. He permitted every eligible Roman citizen to join the army and thus to pursue the career of a professional soldier. Rome then put soldiers on the payroll. Rome also paid for arms, bodily protection, and other necessities. Marius tasked seasoned soldiers with providing field training to the new recruits on the battlefield. The new recruits learned an important lesson: the bravest was the safest. After expeditions, Marius divided the booty equally among his soldiers as an incentive to encourage victory and reward bravery. These practices stood in stark contrast to the Servian Segregation Decree, which Rome enforced during the reign of King Servius Tullius (578 to 534 B.C.). The Decree prohibited the poorest citizens from becoming Roman soldiers. The drafted soldiers also had to pay for their own arms, bodily protection, and other necessities. At the end of the war, they were discharged to return to their former civilian careers, such as farming and smithing. After the Marius era, the employment rights based on the army administration had evolved and fully developed to cover every step of the Roman soldier employment process: recruitment, enrollment, training and development, employment conditions, performance appraisal, and punishment. This process became one of the Roman army's key success factors for the next several hundred years. Modern management practitioners should incorporate the Roman army administration process into the legal obligations within the company's employment policy. The legality of the policy is a result of the adoption of the United Nations Declarations, Conventions, and Covenant into member states' local laws and regulations. This paper focuses on the documentary research method to analyze and assess the relevant documents.
\end{abstract}


Keywords: Employment rights, Gaius Marius, Servius Tullius, Roman army, war

\section{INTRODUCTION}

Employment is a legal and moral obligation binding the employees and the employer to use the utmost effort to accomplish a common organizational mission and goals. The legal obligation will be based on the human and employment rights as specified under the laws and rules of a particular country where the company operates. The objective of this study is to demonstrate the usefulness of the history of Rome to modern-day business administration.

Therefore, this article is divided into three sections:

1. The history of the employment rights of the Roman soldiers.

2. The employment rights of the modern day employment under the guidance of the United Nations agencies.

3. A comparative study of employment rights between the Roman soldiers and the modern day employees.

\section{Research Method}

This article applies the documentary research method (DSM) to analyze and assess the documents. This, therefore, was done in the first two sections based on the following criteria: authenticity, credibility, representativeness, and meaning (Scott, 2006; Ahmed, 2010). For example, the historical books in the first section written by Livy, Sallust, and Plutarch were published by Harvard University Press. The documents in the second part were derived from websites that belongs to reliable organizations, such as the United Nations, Wikipedia, and so on.

\section{THE HISTORY OF THE EMPLOYMENT RIGHTS OF THE ROMAN SOLDIER}

This section draws on the following works:

Livy's History of Rome, Book I (Livy, 1919) covers the period from King Romulus to King Servius Tullius of the Roman Kingdom. Titus Livius was born in 59 B.C. and died in A.D. 17. He wrote in Latin.

Sallust's The War with Jugurtha (Sallust, 1921) covers the era of Gaius Marius, the consul of the Roman Republic who founded the professional army. The author, Gaius Sallustius Cripus, a Roman historian, was born in 86 B.C. and died in 34 B.C.

Plutarch's Lives IX: Demetrius and Antony Pyrrhus and Caius Marius (Plutarch, 1920) also covers the era of Gaius Marius. Plutarchus, the author, a Greek historian, was born in A.D. 45 and died in A.D. 120. He moved to Rome to serve the Roman Empire during the reign of the emperors Trajan and Hadrian. 
Flavi Vegetius Renatus wrote Epitoma Rei Militaris, Liber I (Vegeti, 1872) which was published in Stuttgart in 1872 and Liber II (Vegeti, 1885) in Leipzig in 1885. The Latin versions are available from the Internet Archive. Information about Vegetius is very limited. Thus, he wrote his books in A.D. 390.

Furthermore, the transformation period comprised of four eras:

1. Romulus: The Formation of the Roman Army

2. The Servian Decree: The Formation of the Citizen Army

3. The Marian Act: The Formation of the Professional Army

4. The Subsequent Army Administration and Employment Rights

\section{Romulus: The Formation of the Roman Army (Livy, 1919)}

Basically, one can divide this era into two periods:

1. Prior to the Founding of Rome (753 to 717 B.C.)

The Roman army evolved from a band of shepherd's twin brothers, Romulus and Remus, assembled. The band grew bigger and bigger.

2. After Rome Was Founded

After Rome was founded in 753 B.C., the band of young men grew into an army. The army comprised of an infantry and a cavalry. The cavalry enhanced the effectiveness of the infantry.

\section{The Servian Decree: The Formation of the Citizen Army (Livy, 1919)}

King Servius Tullius (578 to 534 B.C.) systematically divided Roman citizens into classes after the completion of the census based on estimates of the citizens' financial net worth or worthiness. Those capable of bearing arms who failed to register would be punished by death or imprisonment. Roman males were forced to join the army. The main purpose of the classification was to enroll specific classes of citizens in the army. These citizens had to provide money to the treasury. The citizens in the first five classes were eligible to join the infantry. The rest, the poorest of the male population, were exempted from military service. This discrimination against the poorest was intentional because the drafted soldiers had to share the financial burden with the Roman administration. Every soldier had to provide for his own arms and other necessities. The soldiers in the first three classes were allowed armor. Therefore, the following are the Servian classes;

\begin{tabular}{|c|c|c|}
\hline Class & Bodily Protection & Offensive Weapons \\
\hline First & $\begin{array}{l}\text { Helmet, rounded shield, } \\
\text { greaves, breast-plate }\end{array}$ & Spear and sword \\
\hline Second & $\begin{array}{l}\text { Helmet, oblong shield, } \\
\text { greaves }\end{array}$ & Spear and sword \\
\hline Third & Helmet, shield, breast-plate & Spear and sword \\
\hline Fourth & No & Spear and javelin \\
\hline Fifth & No & Sling with stones \\
\hline
\end{tabular}


The soldiers would assemble on the battlefield after the war erupted. After the expedition, the soldiers were allowed to return to their residences to carry on their normal lives as Roman citizens. They were farmers, traders, smiths, and so on. In return, infantry soldiers were given the political privilege to cast votes. The number of votes they were permitted depended on their class. They stood lower on the hierarchy than the cavalry. Members of cavalry were drafted from another social class, the leading men of the state, city, or community. They also served the army without pay, but received an allowance to care for their horses.

\section{The Marian Act : The Formation of the Professional Army (Plutarch, 1920)(Sallust, 1921)}

Gaius Marius (157 to 86 B.C.), who held consulship of the Roman Empire seven times, was a reputable and brilliant military commander. He had a vision and a solid determination to build a strong Roman army, ideally comprised of a brilliant military commander with a proven military record and the bravest soldiers. This, therefore, would make it easier for the Roman army to win wars with a minimum of casualties. Another benefit of having a strong army was that the enemy would pledge alliance to Rome. The idea was that Rome could win without sacrificing the lives of Roman soldiers by spending some of the Republic's treasury. After performing a situational analysis, Marius identified the major obstacle to his reform. He recognized that strong resistance could come from the Senate and several other fronts. Thus, the following are some of his requests that resulted to drastic changes from the Servian decree:

1. To recruit and select the soldiers from every level of Roman society, regardless of their socioeconomic status. He believed that the bravest and most competent soldiers were not necessarily part of the nobility. The poorest could be the bravest. By enlarging the pool of candidates, he could select the best soldiers for the army.

2. To allow Romans the choice to pursue a career as soldiers or remain in their current careers. Becoming a Roman soldier would no longer be compulsory.

3. To shift the financial burden from the soldiers to the Republic because the soldiers would be employed by the Republic or be on the Republic's payroll. Rome would provide arms, bodily protection, and other necessities. These men would be hired to fight as professional soldiers.

4. To establish a minimum military age to avoid enlisting child soldiers.

Consequently, to overcome the resistance to change, Marius employed the following strategic and tactical approaches: 
1. He turned an external threat to the Republic into a personal opportunity. By that time, the Jugurthian War had dragged on since 112 B.C. Marius asked for his first consulship from the Assembly with a promise that he could either kill or capture Jugurtha alive. He got his first consulship in 107 B.C. He also took this opportunity to reorganize and enlarge the Roman army to fight the Jugurthian War.

2. He successfully criticized the fundamental weakness of the Servian Decree, which caused the following problems for Rome.

2.1 Servius had discriminated against the poorest citizens, preventing them from joining the army. Some of these left out citizens could be brave, strong, capable fighters. They had the potential to be successful soldiers.

2.2 The military commanders struggled to manage with scarce human resources.

2.3 Becoming a soldier of the citizen army was initially a career path to a higher political position. Such soldiers might not be loyal and lacked the personal determination to devote themselves to the army.

2.4 The drafted soldiers were forced against their will by the Decree to serve in the army without pay, and the soldiers had to pay for their arms, bodily protection, and other necessities. This was a demotivating factor.

3. Gaius Marius proposed the new law to provide equal opportunity to every eligible Roman citizen who had reached the military age to voluntarily join the army. However, members of the Senate, who were prejudiced against the poor, hesitated to agree to Marius' request to enlarge the number of citizens eligible to fight Rome's enemies.

4. The Senate, who had no choice, eventually enacted the law to replace the Servian Decree. The Act was a part of the Marian Reforms. The Act allowed the military commander, starting with Marius, to enroll and employ every eligible Roman for military service. The Senate still believed that by giving equal opportunity to the citizens, Marius would eventually lose the public devotion.

Gaius Marius took the following steps to form the professional army:

1. Persuasion and Encouragement: He assembled the eligible Roman citizens to persuade and encourage them to join the army under his leadership. He said he was elected to be a consul by the Senate because of his merits, ability, integrity and bravery, not by nobility of birth. He criticized Bestia and Albinus, noblemen by birth, who failed to command the army. Marius made it a point that, on contrary, he was a successful commander with a proven record who had not come from the point of nobility. He also showed off his wounds.

2. Motivation: He motivated them to join the army by offering the following remuneration, rewards, and honors. 
2.1 Compensation for military service as follows: Every soldier was employed by the Republic and was on the Republic's payroll. Rome also provided arms, bodily protection, and other necessities.

2.2 Rewards: At the end of an expedition, he gave an equal portion of the booty to every surviving soldier. The proposed inducements were highly motivating and made every man feel rich.

2.3 Honors: The soldier also received an honor upon returning home as a victor. A victor met the following major qualification: the ability to fight with bravery and survive. This latter became one of the key success factors of the performance appraisal for honors, promotion, and advancement for Roman soldiers.

3. Enrollment: Marius enrolled eligible citizens into main military units, an auxiliary and a legion, of the Roman army.

3.1 Auxiliary: Marius enlisted the bravest men, on a voluntarily basis, from the diversified foreign nationals, regardless of their nationality, social origin, language, race, ethnicity, or status.

3.2 Legion: Marius enlisted volunteers from a diversified group of prospective soldiers, regardless of their property, net worthiness, agedness, or experience. They were the active soldiers who were ready for combat and who he knew from actual service, but only a few already had a reputation. They were veterans, regardless of age or agedness, based on their record, ability, and bravery and wished to rejoin active service. Those who were not soldiers before, at the eligible age, were invited to voluntarily join the army regardless of their socioeconomic status.

4. Battlefield Training: New soldiers fought alongside experienced soldiers. They learned to enter the battlefield fearlessly. They learned one of the most important lessons: The bravest was the safest. Within a short time, the old and the new soldiers were assimilated, and all became equally courageous.

\section{The Subsequent Army Administration and Employment Rights (Vegeti, $1872 \& 1885)$}

The administration of the Roman army after the era of Gaius Marius, as described by Flavi Vegeti Renati or Flavius Vegetius Renatus, had further developed to enhance the effectiveness of the professional army, as follows:

1. Training and Development: The soldiers were divided into two groups as described below:

1.1 After the new soldiers were enrolled in the Roman army, they had to engage in daily exercise during their probation period of at least four months. If they passed, they received military marks imprinted on their hands. Then they had to take the military oath prior to becoming official soldiers. They would be discharged if they failed. 
1.2 During peacetime, both the newer soldiers and the veterans went through the drills every day all year. The well-trained soldiers were eager for action.

2. Additional employment conditions were available besides the compensation and rewards.

2.1 Leaves or holidays were granted to the Roman soldiers, with an exact timeframe and limitations.

2.2 Healthcare: Physicians and veterinarians treated the sick and wounded soldiers and animals, respectively.

2.3 Welfare: Recuperation centers were available for disabled soldiers and veterans. For example, there was a recuperation and healing center located in Hierapolis near Pamukkalae, in modern-day Turkey. (en.m.wikipedia.org) 3. Performance Appraisal: The Roman military commander regularly evaluated the performance of his troops. The appraisal was based on merits, such as bravery, ability to fight, and years of service or survival rate. The recorded results of the appraisal would be used for the following considerations and military management.

3.1 The merit system provided a fair and equal opportunity for advancement or promotion in ranking and pay, or a job rotation for the Roman soldier to gain new experience.

3.2 The merit system rewarded outstanding soldiers with honors, money, and/or prizes.

3.3 The merit system provided a job enrichment program, such as a job rotation, for active soldiers. soldiers.

3.4 The merit system corrected and developed underperforming 4. Additional Benefits

4.1 The veterans were entitled to retirement benefits, such as land and money.

4.2 The Roman soldiers were obliged to deposit half of their pay. The reserves were maintained at the public's expense. The soldiers knew their future fortunes and had no thought of desertion. There was also a common fund to defray expenses for deceased soldiers.

5. Punishments: If a soldier committed a crime, he would be punished or jailed.

\section{EMPLOYMENT RIGHTS OF THE MODERN-DAY EMPLOYEE}

Industrialization, which began in the eighteenth century, transformed an agrarian economy into an industrial one to serve the rise of the new economy and society in Western countries. The farmers were hired to work in factories and became laborers. These laborers were freely exploited by the owner of the manufacturing enterprises, through various methods and forms, violating human and employment rights. To protect the rights of the laborers, 
the International Labour Organization was founded. It aimed to correct the worsening employment situation. The International Labour Organization (ILO) was founded on April 11, 1919 by the League of Nations, under the Treaty of Versailles, as an independent affiliated agency. The ILO was dissolved with League of Nations during World War Two and reincorporated into the United Nations as the first specialized agency. The ILO continues to maintain its active role in developing and promoting a system of international labor standards by holding conventions, which are the instruments that upon ratification create legal obligations, legislation, and practice by member states; and issuing recommendations, which are not open for ratification, but give guidance to member states, through declarations, conferences, and publications. The principles and rights at work under the declarations and conventions can be summarized as follows.

\section{Enrollment in a Work Force}

1.1 Elimination of forced or compulsory labor.

1.2 Elimination of discrimination related to differences in demographic and geographic origin.

1.3 Equal employment for men and women.

1.4 A minimum age for employment.

\section{Rights at Work}

2.1 Fair wages and benefits.

2.2 A limitation on working hours or hours of work.

2.3 Adequate rest, leisure, and paid holidays.

\section{Protections}

3.1 Occupational hazards in specific industries and industrial accidents.

3.2 Termination of redundant employees.

3.3 Employer's insolvency.

3.4 Maternity leave.

3.5 Unemployment.

\section{Industrial Relations}

4.1 Freedom of association.

4.2 Collective bargaining.

4.3 Consultation.

4.4 Grievances.

At present, the ILO's declarations and conventions cover employment rights for employees in the private sector and industry. (www.ilo.org)

The Universal Declaration of Human Rights (UDHR) was enacted by the member states of the United Nations on December 10, 1948, in recognition of the general rights of the individual. There are thirty articles in the Declaration, which could be divided into two groups, basic or general and specific rights. The specific rights of every individual are divided into several 
subgroups, such as legal rights, civic and political rights, and employment rights. (un.org/en/documents/udhr) The employment rights under the UDHR are to reinforce the ILO's conventions and recommendations. The following is a summary of the employment rights under Article 1 and 2 of basic rights and Article 23 and 24 of specific employment rights.

1. Basic Rights

Every individual is entitled to all declared employment rights regardless of the difference in demographic and geographic origin or ancestry. 2. Specific Employment Rights.

2.1 Enrollment Rights: Every individual has the right to a free choice to be enrolled.

2.2 Conditions of Work Rights: The employer must provide just and favorable working conditions.

2.3 Protection against unemployment.

2.4 Rights at work.

2.4.1 To receive fair and sufficient remuneration for the entire family with supplementary social protection.

2.4.2 The right to form or join a trade union.

2.4.3 The right to limitations on working hours.

2.4.4 The right to rest and leisure.

2.4.5 The right to periodic paid holidays.

The United Nations enacted two international covenants or treaties, the International Covenant on Civil and Political Rights (ICCPR) and the International Covenant on Economic, Social and Cultural Rights (ICESCR) (en.wikipedia.org). The two covenants were adopted by the General Assembly of the United Nations in December 1966 and became effective in 1976. Articles 6, 7, and 8 of the ICESCR are related to employment rights, which can be summarized as follows:

1. The individual has the right to work.

2. After the individual is employed, he or she is entitled to the following rights:

2.1 The right to fair and just treatment in compensation.

2.2 The right to equal opportunity for advancement.

2.3 The right to work under safe conditions.

2.4 The right to work within limited working hours.

2.5 The right to rest, leisure, and paid holidays.

3. Every employee has the right to unionize.

\section{A COMPARATIVE STUDY}

The following is a comparative study between what had been practiced by the Romans regarding the employment rights of the Roman soldier with the Declarations, Conventions, and Covenants of the United Nations. 


\section{The United Nations}

\section{Non-discrimination Against}

Race

Color

Sex

Language

Religion

Nationality

Social Origin

Birth or status

Disadvantages

Enrollment

Free choice of employment

Elimination of forced or compulsory

The right to work

Equal access to employment

Avoid child labor

\section{Employment Conditions}

Probation for new employee

Fair wage and equal pay

Favorable remuneration

Sufficient rest and leisure

Limited working hours

Regular period of holiday with pay

Safe and healthy working conditions

Paternity leave

Protection against unemployment

and severance payments

\section{The Roman Army Administration}

Race and ethnicity

Language

Social Origin

Nationality

Birth or status

Agedness

Free choice to join the army

Without forced employment or labor

The right to choose the career

Equal access to join the Roman army

Setting up an eligible age to join the army

Probation for new recruits

Equal divided booty

The Roman soldier felt rich with the offers

Sufficient rest and leisure during peace time

Exact time and limitation of furloughs

Camp was chosen with great care

Physicians to take care of sick soldiers

Soldier deposits will be given for lawful discharged or deceased

Retirement benefits to the veterans

\section{Performance Evaluation}

Equal opportunity for advancement

Equal opportunity for promotion

based on performance appraisal system.

\section{Unionize or Industrial Relations}

The right to form or to join a trade union, collective bargaining and strike.

Mutiny was illegal and might face severe punishment.

\section{SUMMARY AND CONCLUSION}

In 107 B.C., the Roman Senate, through Consul Gaius Marius' initiative, established a new act that allowed Marius to reinforce his army to fight the Jugurtha. The act was a part of the Marian Reforms and it replaced 
the Servian segregation decree, through which citizens were classified into six classes based on their net worthiness. The citizens in the first five classes were allowed to join the army. The poorest citizens, in the sixth class, were prohibited from becoming Roman soldiers. The soldiers were obliged to pay for their own arms, bodily protection, and other necessities. The new act allowed Marius to enroll, enlist, and employ every eligible Roman citizen in the professional army. These men received equal rights and opportunity. The soldiers were under the payroll of the Roman Republic. Rome also paid for arms, bodily protection, and other necessities. The soldiers were entitled to receive various benefits, besides regular pay, such as an equal portion of the booty after an expedition and retirement benefits. After the Marius era, the army administration evolved and developed further by introducing more human management procedures, such as the performance appraisal system and the soldier's deposit, which enhanced the effectiveness of the administration. Almost two thousand years after the Marian reforms, the ILO was established by the League of Nations in 1919 to protect the rights of the laborers who were exploited by their employers during the Industrial Revolution. The ILO was dissolved during World War Two and reestablished again under the United Nations in 1946. In 1948, the UDHR was created by the member states of the United Nations. The UDHR included employment rights. In 1966, the ICESCR was adopted and open for signature, ratification, and accession by the General Assembly of the United Nations. Employment rights form part of the ICESCR. It became effective in 1976. Both Roman and modern-day employment rights share a common purpose and administration procedures, with the exception of the performance appraisal system, which was a part of the Roman army's administration, but was not established under the Declarations, Conventions, and Covenants of the United Nations. The management of the modern enterprise is recommended to integrate the legal rights under local laws and United Nations Declarations, Conventions, and Covenants with the performance appraisal system of Roman army administration and the moral obligation to create an effective and efficient employment policy and procedures, which are an essential part of human management. The discovery is the only beginning that shows the connectivity between historical events and modern management. Let's explore further.

\section{References:}

1. Armed, J.U. (2010). Documentary Research Method: New Dimensions, Indus Journal of Management \& Social Science, 4(1): 114 (Spring 2010).

2. Livy Titus (1919). History of Rome, Book I. Translated by B.O. Foster. Boston: Harvard University Press, p. 148-152. 
3. Plutarch (1920). Lives IX: Demetrius and Antony Pyrrhus and Caius Marius. Translated by Bernadotte Perrin. Boston: Harvard University Press, p. 483-495.

4. Sallust Gaius (1921). The War with Jugurtha. Translated by J.C. Rolfe. Boston: Harvard University Press, p. 308, 310-322, 324.

5. Scott, J.P., (Ed) (2006). Documentary research. Thousand Oaks, CA : Sage Publications.

6. Vegeti Flavi (1872). Epitoma Rei Militaris, Liber I. Stuttgart, ia802205.us.archive.org.

7. Vegeti Flavi (1885). Epitoma Rei Militaris, Liber II. Leipzig. ia802205.us.archive.org.

8. en.wikipedia.org $>$ wiki $>$ Hierapolis

9. ICCPR, www. en.wikipedia.org

10. www.ilo.org

11. www.un.org/en/documents/udhr 